\title{
A HAZARD OF EPIDURAL ANAESTHESIA IN OBSTETRICS
}

\author{
A. C. Webster, B.SC., M.B., CH.B., F.F.A.R.C.S.*
}

THE CASE TO BE DESCRIBED is one in which extremely high anaesthesia resulted from an epidural block performed on a multipara late in the first stage of labour, using a standard technique and a recommended dose of anaesthetic agent. A possible explanation is suggested.

The patient was a para 3, gravida 4 . There was a history of "fainting"|when local anaesthesia was given for dental treatment several years ago. Epidural anaesthesia was chosen for delivery, and at the time of administration uterine contractions were occurring at 2 to 3 minute intervals, the cervix being about six centimetres dilated with the vertex below the plane of the ischial spines. The membranes had ruptured spontaneously.

With the patient in the left lateral position the epidural space at the level of the L3-4 interspace was identified by a "loss of resistance" method, using a 2 c.c. syringe loaded with air attached to a No. 16 Tuohy needle. The epidural space was entered with ease and a test dose of 5 c.c. of 1.5 per cent Lignocaine with epinephrine $1: 200,000$ given. After an interval of 5 minutes, during which time the pain of uterine contractions was abolished, the signs of spinal anaesthesia did not supervene and the main dose of 15 c.c. of the same solution was injected slowly. During the next fifteen minutes the patient first became aware of weakness and numbness of the legs with the level of anaesthesia rising progressively until weakness and numbness of the hands and arms ensued. The blood pressure fell and an intravenous infusion of 5 per cent glucose in water was started. Normal blood pressure was promptly restored with small intravenous doses of methoxamme. During this time the patient was nauseated and vomited; she complained of dysphagia and dyspnoea and became terrified. The level of analgesia extended to the supra-sternal notch. There was no cyanosis and the tidal exchange was adequate; the patient was able to breathe more comfortably in the lateral position. For her extreme agitation she was given, about half an hour after the block was induced, an intramuscular injection of meperidine $50 \mathrm{mg}$. with promethazine $50 \mathrm{mg}$., immediately followed by $\mathrm{N}$-allyl-nor-morphinone $5 \mathrm{mg}$. intravenously. it

Approximately one hour after the block was started, routine low forceps delivery was performed. The infant was slow to breathe but regular rhythmical respiration became established within a minute of birth without resuscitation other than pharyngeal suction and administration of oxygen by a funnel. There was, howèver, inspiratory indrawing of the lower ribs and sternum and a paediatric opinion was sought. The infant was considered to have a respiratory distress syndrome. There was no meconium in the amniotic fluid.

Following delivery the patient lapsed into sleep from which she awoke with no residual ill-effects apart from the memory of a most unpleasant experience. The

*19 Summerhayes Cres., R.R. \#6, Brantford, Ontario.

Can. Anaes. Soc. J , vol. 9, no. 5, September, 1962 
dysphagia is a feature difficult to explain other than on a functional basis, but the evidence is otherwise overwhelmingly in favour of extremely high epidural block.

\section{DIsCUSSION}

The height of epidural anaesthesia is determined by the site of injection, the position of the patient, the rate of injection, the volume of local anaesthetic agent given relative to the volume of the epidural space, and the patency of the communications through the intervertebral foramina with the paravertebral space. ${ }^{1}$ Strict accuracy in estimating the dose of anaesthetic agent necessary to produce a given level of anaesthesia is not easy to achieve. In most circumstances an approximation is permissible because the hypotension produced takes place gradually and marked paralysis of respiratory muscles is not a feature of high epidural block.

That the height of epidural anaesthesia in obstetrics, when carefully induced by standard methods and doses of anaesthetic agent, is variable and unpredictable is reflected in the incidence of hypotension. The same variability with the occasional incidence of very high anaesthesia is a factor that led to the decline in popularity of spinal anaesthesia in obstetrics. The anatomical and physiological basis of this phenomenon may well be similar in both methods.

The internal vertebral plexus of veins ${ }^{2}$ that occupies mainly the anterior and lateral part of the epidural space has rich segmental communications at all levels via the intervertebral veins which pass out through the intervertebral foramina, with the vertebral, posterior intercostal, lumbar, and lateral sacral veins, which drain via the innominate, azygos, and hemiazygos, ascending lumbar and internal iliac veins, into the superior and inferior vena caval systems respectively. By jugular and abdominal compression in Queckenstedt's test, the relationship between increased venous pressure and increased cerebrospinal fluid pressure is demonstrated. Absorption of cerebrospinal fluid into the cranial venous sinuses and vertebral veins by the arachnoid villi is hindered and cerebrospinal fluid pressure rises. ${ }^{3}$ Alterations in cerebrospinal fluid pressure by coughing and straining are similarly produced via the venous network described.

It is postulated that increased pressure in the inferior vena cava and internal iliac veins caused by influx of blood from the uterine veins during the powerful uterine contractions of the latter part of the first stage and the second stage of labour may also be transmitted to the epidural veins. Furthermore, when the patient is in the left lateral position with the thighs fully flexed, the gravid uterus may be forced against the posterior abdominal wall, tending to compress the inferior vena cava and encourage the entry of blood from the uterine veins into anastomotic channels. It has been suggested that increase in cerebrospinal fluid pressure coincident with uterine contractions is responsible for the high spread of anaesthesia often observed when spinal anaesthesia is given to the woman in labour. Pressure changes in the epidural space accompanying uterine contractions have been demonstrated by Bromage. ${ }^{4}$

Similarly it may be postulated that in the citcumstances described, during uterine contractions the volume of the epidural space available to accommodate 
injected local anaesthetic agents will be diminished in proportion to the amount of blood distending the epidural veins. At the same time the exits from the epidural space are restricted by engorgement of the intervertebral veins. Therefore fluid injected into the epidural space during uterine contractions may readily track to high levels.

If these suppositions are correct, the potential dangers of giving a test dose become apparent. Identification of the epidural space is performed in an interval between uterine contractions while the patient can be persuaded to be still. The test dose which may then be given may abolish completely the pain of $\mu$ teririe contractions. Should the subsequent injection of the main dose of the local anaesthetic agent then coincide fortuitously with a painless uterine contraction, the resulting level of anaesthesia may become unexpectedly high. This may well be the explanation for the case that I have described.

It is therefore suggested that if a test dose has been given, then an experienced hand should be on the patient's abdomen to detect the presence of uterine contractions. Extreme flexion of the thighs should be avoided and the epidural injection given soon after a uterine contraction has subsided so that there is time for the local anaesthetic agent to become fixed or to diffuse from the epidural space before the next contraction occurs. Alternatively, stronger reasons may exist than those previously given ${ }^{5,6}$ for the omission of the test dose.

\section{SUMmary}

A case of extremely high epidural anaesthesia given to a multipara for vaginal delivery is described. A possible explanation is offered with recommendations designed to minimize the incidence of high spread of epidural anaesthesia in obstetrics.

\section{RÉSUMÉ}

Nous rapportons un cas d'anesthésie épidurale très haute à la suite d'un bloc lait chez une multipare, à la fin du premier stage du travail, bloc où nous avons employé une technique standard et une dose ordinaire d'agent anesthésique. Nous essayons d'expliquer cela.

Nous attirons l'attention sur la fréquence variable et imprévisible de l'hypo-

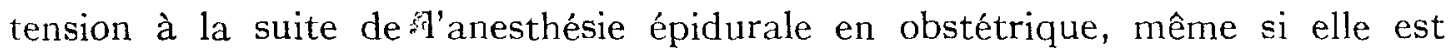
pratiquée avec soin, en employant des méthodes standards et des doses ordinaires, et cette hypotension témoigne de la hauteur variable de l'anesthésie épidurale en obstétrique. Les mêmes faits observés occasionnellement de très hautes anesthésies est un facteur qui a fait perdre de la popularité à la rachianesthésie en obstétrique. L'on peut croire que la base anatomique et physiologique de ce phénomène est la même avec les deux méthodes.

On présume que les changements de pression dans les veines du bassin à l'occasion des contractions utérines sont transmis aux veines de l'espace épidural par leurs communications avec les veines sacrées latérales, les veines lombaires ascendantes et les veines intervertébrales. En plus, lorsque la malade est couchée sur le côté, les cuisses fléchies au possible, l'utérus gravide peut être poussé vers 
la paroi abdominale postérieure, exerçant ainsi une compression sur la veine cave inférieure et forçant le sang à entrer dans les veines anastomotiques. Il est possible que, dans ces circonstances, au cours des contractions utérines, le volume de l'espace épidural libre pour contenir les agents anesthésiques injectés soit diminué proportionnellement à la distension des veines épidurales par le sang. Au même moment, la sortie du sang de l'espace épidural est limitée à cause de l'engorgement des veines intervertébrales. Alors, un liquide injectê dans l'espace épidural, au cours des contractions utérines, ne peut se trouver un chemin que vers le haut.

$\mathrm{Si}$ ces suppositions sont vraies, les dangers possibles de donner une dose d'épreuve deviennent manifestes. L'identification de l'espace épidural se fait entre deux contractions au moment où l'on peut convaincre la malade de ne pas bouger. La dose d'épreuve que l'on réussit à donner, à ce moment-là, peut abolir complètement les douleurs des contractions utérines. Si l'injection subséquente de la dose principale de l'agent anesthésique local coincide par hazard avec une contraction utérine indolore, le niveau d'anesthésie qui s'obtient peut, à notre surprise, devenir très haut.

Nous suggérons donc, si l'on donne une dose d'épreuve, de placer une main entraînée sur l'abdomen de la malade pour percevoir l'apparition des contractions utérines. Il faut éviter de fléchir les cuisses de la malade et l'injection épidurale doit être faite aussitôt après une contraction utérine pour que l'agent anesthésique local soit fixe ou ait le temps de diffuser en dehors de l'espace épidural avant l'apparition de la contraction utérine suivante. De plus, il peut exister d'autres raisons meilleures que celles que nous avons données antérieurement pour omettre la dose d'épreuve.

\section{REFERENCES}

1. Wylie \& Churchild-Davidson. A Practice of Anaesthesia, p. 873. London: Lloyd-Luke Ltd. (1960).

2. Bromsge, P. R. Spinal Epidural Anaesthesia, p. 9. London and Edinburgh: Livingstone (1954).

3. Wright, Samson. Applied Physiology, 9th ed., p. 123. London: Oxford Lniversity Press (1952).

4. Bromage, P. R. Continuous Lumbar Epidural Anaesthesia in Obstetrics. Canad. M.A.J. 85: 1136 (1961).

5. Eisen, S. M.; Rosen, N.; Winesanker, H.; Hellmay, K.; Axelrod, H. I.; Rotenberg, M.; Relle, A.; \& Sheffman, E. The Routine L'se of Lumbar Epidural Anaesthesia in Obstetrics: A Review of 9,532 Cases. Canad. Anaesth. Soc. J. 7: 280 (1960).

6. Chaplin, R. A. \& Renwick, W. A. Lumbar Epidural Anaesthesia for Vaginal Delivery. Canad. Anaesth. Soc. J. 5: 414 (1958). 